\section{Minor Myers, Jr.}

Minor Myers, Jr., 17th president of Illinois Wesleyan University, student of political philosophy, and passionate advocate for the liberal arts, passed away on July 22, 2003 in Bloomington, Illinois. He was 60 years old.

Myers was born in Akron, Ohio, in 1942. In 1964 he earned a bachelor's degree from Carleton College in Minnesota. Undertaking graduate studies first at Duke University and then at Princeton University, he completed a master's degree at Princeton in 1967. The following year he took a faculty position at Connecticut College. He completed his Ph.D. in politics and political philosophy at Princeton in 1972. His dissertation, titled "British Laws of Nature, 1640-1785," was an early example of Myers' life-long fascination with Anglo-American philosophy, history, and law.

Rising through the ranks to become department chair at Connecticut College, Myers taught mainly political theory. His interests were wide, including American and European history and the arts. He was, according to Bill Frasure, professor of government and former colleague to Myers at Connecticut College, "fascinated with just about everything. He had a fast and wide-ranging mind." Easily among the most popular teachers at the college, waiting lists regularly developed to enroll in his classes. He was funny, articulate, and a good lecturer. He had, according to Frasure, a huge following. His innovative ideas regarding curriculum were a tremendous boon to that institution. Myers' dedication to inter-disciplinary work led him to insist on non-political scientists helping with searches for new faculty, a practice that has since become standard at many institutions.

During the 1981-1982 year Myers spent a sabbatical in residence at Brown University. Upon his return to Connecticut College he assumed the post of administrative assistant to the president and dean of the faculty. In 1984 Myers was appointed the provost and dean of the faculty at Hobart and William Smith Colleges in Geneva, New York. There he earned a reputation as a strong supporter of both the curriculum and of academic research among the faculty. Hobart College Dean and former colleague Clarence Butler said of Myers, "he was truly a Renaissance man. I've never met someone who knew so much about so much."

In 1989, Myers was named president of Illinois Wesleyan University. During his 14-year tenure there he oversaw significant growth in the size of the faculty, a notable rise in the selectivity of its student admission process, and a building campaign amounting to some $\$ 115$ million in renovations and new construction, including a new library, a new center for natural sciences, a new physical education facility, and a new student center. Academically, Illinois Wesleyan flourished under Myers. The university was granted a Phi Beta Kappa chapter in 2000. Semester-long study abroad programs in London and Madrid were established, and exchange programs were created with Pembroke College of Oxford University and Obirin and Keio universities in Tokyo. Numerous new majors and minors were also added to the curriculum.

Myers constantly reminded Illinois Wesleyan's students that the goal of their education was not simply to find a job but to find and follow their fascinations. Myers lived this out by way or example, authoring or co-authoring eight books and numerous articles, playing the harpsichord, and collecting coins. His original musical play, "The College Inn Revisited," was performed by the Chicago Historical Society in 1994. It focused on the 1920's jazz movement in Chicago and the role that city played as a launching ground for Broadway theatre in New York. His particular fascination with the 18th century led to his expertise in furniture, musical instruments, publishing, and higher education during the American colonial period.

Myers' books included Liberty without Anarchy: A History of the Society of the Cincinnati (1983), The Insignia of the Society of the Cincinnati (1998), and A Documentary History of American Interiors from the Colonial Era to 1915 (1980). The 1983 work stands as a thoroughgoing chronicle of the Society of the Cincinnati, whose members are descendents of American Continental Army or Navy officers. Myers was the first scholar granted complete access to the Society's documentary archive. From 1986 until 1988 he served as the Society's secretary general. He also produced various journal articles on topics including the history of crime and punishment, the history of an Episcopal church congregation in Connecticut, and several articles on numismatics, one of several hobbies he pursued earnestly. He also co-authored The Princeton Graduate School: A History in 1996.

Myers helped guide several educational organizations and institutions, serving on the boards of directors of the Foundation for Independent Higher Education, the Associated Colleges of Illinois, the Institute for the International Education of Students, and the Lyman Allyn Museum at Connecticut College.

Illinois Wesleyan Provost and Dean of the Faculty Janet McNew noted of Myers that "he was the very model of a liberally educated person whose interests ranged far and wide, and who cherished learning as an end in itself."

Craig Hart, president of the Illinois Wesleyan Board of Trustees said of Myers, "His enthusiasm was infectious. He was a joy to be around."

Ed Rust, Illinois Wesleyan alumnus and Chairman and CEO of State Farm Insurance Companies, noted on Myers' passing that "many of Illinois Wesleyan's remarkable achievements over the past decade and more can be directly attributed to Minor's enthusiasm and his pride in the institution and its students. It was contagious."

Myers is survived by his wife, Ellen, and their two sons, Minor III, and Joffre.

Greg M. Shaw Illinois Wesleyan University

\section{Sir Bernard Williams}

Professor Sir Bernard Williams, born September 21, 1929, died June 10, 2003 in Rome on holiday. The London Times reported that Sir Williams will be remembered as the most brilliant and most important moral philosopher of his time. After several prestigious academic appointments in England and America he split his time between Berkeley and All Souls College, Oxford. He wanted, "to live a whole life well." Often difficult to assess the extent to which others capture what they aspire to, Williams always seemed complete. An expert pilot serving in the RAF, accomplished composer, lover of sports and fast cars; Williams enjoyed himself. Those who knew him will remember his keen wit, sarcastic grin, deadpan humor, hearty laugh, and magnetic storytelling. As for his reputation for combativeness, he was relentless but not (as far as I know) mean spirited. A tutorial could spiral 
out of control causing both participants to rise to their feet, yet his pinpoint accuracy and intrinsic dedication for the subject could inspire an extraordinary sense of peace.

Known mostly for contributions to moral philosophy, Williams for some time became fascinated with what he called the "political," using it as a prism refracting light on nearly everything he most wanted to say. This notion, moreover, promises to serve the field of political science in both its theoretical and empirical aims. In 1995, Williams led the plenary session of the American Political Science Association meeting entitled, "Moralism and Realism in Liberal Theory." The message was clear, though as we shall see, its implications deep and far-reaching. Political theory needs to be more than applied moral philosophy. The revival in normative political philosophy, largely inspired by the work of John Rawls, Nozick, Oakeshotte, and postmodern pragmatists, fails to combine the philosophical analysis of political principles with an empirical understanding of political processes. While some of the newer work is philosophically sophisticated, it remains unconcerned with concrete politics, and therefore is poorly grounded empirically and lends little support to social science.

Williams' concern with the political on the other hand, has far reaching consequences for political science. It is involved with institutional analysis and processes in fields relating to American Government. It distinguishes between constitutional principle and political interest. His concern for justice, democracy, tolerance, and diversity influences fields such as comparative politics and American Foreign Policy. Much of Williams' thought on politics and political thought is scattered throughout his published and unpublished work given at public lectures and conferences worldwide. The material, however, has coherence, as was demonstrated in a seminar he offered with Ronald Dworkin in Oxford, Hilary Term 1996, entitled simply, "Democracy." Even this past spring, after successfully battling cancer since 1999, he planned to write two books on the subject. One book would focus on the defense of liberalism in relation to recent history while another promised more ambitious approaches to political history.

Since much of Williams' work in political philosophy is not well known to a general audience, permit me some latitude in explicating its richness and relevance. The context of Williams' political thinking emerged after the Second World War. Here his friend and some- time coauthor, Sir Isaiah Berlin, attempted to distinguish the idea of liberty particularly from ideological determinism and notions of freedom put forward by those who associated any view under the banner of freedom with a semantic good. Thus, Berlin made a sharp conceptual distinction between what he designated as negative liberty which concerned protecting the "lower" self or "true" self from physical coercion and positive freedom, which is deemed by various powers to promote the "higher self" through the development of goals such as autonomy or selfmastery. Berlin found the latter threatening since physical coercion could be justified for some higher cause that may be used to justify such physical coercion for putative rewards promised in the future.

For Williams this distinction is purely political as it distinguished various styles of ruling and being ruled. Moreover, negative liberty was more closely linked to what he viewed as the fundamental source of political authoritycoercive power. So negative liberty, for Williams, is a more legitimate political goal in so far as it is meant to be minimally normative excluding supraphysical normative goals, psychological aspirations, and evaluative ideas.

This minimalism led Williams to a well-known paper entitled, "The Conflict of Values." Some of these ideas assisted Berlin in his work on value pluralism, but it should be clear that Williams meant the piece to be a thesis about the reality of values, not a specific political or ethical justification. Optimistic schemes in politics, religion, and ethics repeatedly attempted to claim that understood correctly, values would not conflict, but dovetail in harmony. For instance, "true" liberty would not conflict with "true" equality. Williams and Berlin rejected such outlooks for at least three reasons. Politically, attempts to put them into practice have always led to disaster, results which only their most fanatical adherents can deny. Ethically, they are an evasion, and pretend that an intellectual construction can make life easier. And, philosophically they are a mistake, (since Williams' view of philosophy is based on the idea that it cannot be constructed through self-sufficient causes this last claim rests largely on the prior two assertions involving materials taken from politics and ethics).

Williams believed that the distinction between negative and positive liberty was explicitly political in the sense that it confronted the notion of direct physical coercion, at issue in much of the ideological politics of the twentieth century. While he believed that negative liberty was an intrinsic rather than merely an instrumental good (Berlin sometimes expressed this view), he distanced himself from what he believed was an inadequate political claim that value pluralism could serve as a foundation for a liberal regime. The claim that value pluralism privileged liberal societies has been criticized by theorists of differing dispositions. Most felt that value pluralism leads to relativism. Williams was not so much concerned with this, but felt that liberty needed to rest on firmer political ground than choice, as this drew closer to the positive liberty of autonomy.

In the late eighties and early nineties he became impressed with the foundation Judith N. Shklar put forward for negative liberty. She thought that negative liberty had been cast in terms that were conceptually distinct from the actual political conditions of liberty. If negative liberty with its goal in protecting the "lower" true self was to be prevented from sliding toward the slippery slope leading to positive liberty, then we needed to specify at least the minimal political institutions and social conditions that will protect such a conceptual distinction. For Shklar, negative liberty was threatened by systematic institutionalized cruelty imposed arbitrarily through governmental agents instilling a protracted irreducible fear. Moreover, avoiding this evil lead to a "moral intuition" that provided convincing support for the principle of liberalism as well as constitutional government.

In his last book, Williams acknowledged Shklar's theory to be the most convincing justification for liberalism. The theory intrigued him since it connected the institutional structure of a free society to puzzling questions regarding the limits of tolerance. Systematic cruelty based on illegitimate governmental coercion had connections to tolerance (internationally as well as domestically) as a public practice rather than an entrenched value such as autonomy, as promoted by liberal thinkers such as Rawls and Nagel. In this sense, the liberalism of fear could, by Williams, be brought to transcend debates about value conflict inherent in pluralism and relativism.

Nevertheless, the matter could never admit of such closure as Shklar had hoped. First, he believed Shklar's theory produced a political rather than moral intuition or good. Otherwise, like any other moral claim it could be used in an a priori manner. This had been the case with Hobbes. So, avoiding fear did 
not necessarily lead to liberal political institutions. While the liberalism of fear was sophisticated in its connections to the empirical world of politics, it could be used broadly, in the wrong hands, to attempt to shape the future according to some moral good conceived prior to political action through various modes of epistemology (in Shklar's case through memory and/or physiological intuition).

Of course, this leads to a vast subject into which Williams delved. Here we can only treat his thoughts in summary fashion. Reaching back to earlier moral critiques Williams had influentially employed regarding Utilitarianism and Kantianism as moral systems, he began to agree with various scholars that the structure and purposes of reflection had shifted in the modern world. Plato's dialogues illustrated this. It's not that they were short on moral and political ideas, but rather that nothing in them straightforwardly reports theoretical findings on which everything was suppose to turn. They remained, in this sense open, inviting contemplation rather than strategy. Modern thought too often contained closed moral visions that were to be taken to accurately shape the future. The morality systems, whether through abstract reason (as in Kant), sympathetic coherence of the concrete natural world (as in Hume), and retrospection (as in Hegel) were attempts to instantiate some prior ethical end directly into the world. Ironically, politics (and its dynamics), the medium through which these goals were to be realized, was not confronted in any sort of evaluative manner.

Nietzsche, Williams thought, was adept at pointing out illusions systematic thinkers claimed as objective truth, yet with no concept of the political, his own ideas became illusory and led only to despair. There is no road back from the Enlightenment (even if we could be taken back through massive coercion it would not be the same as being back). Williams' claim to attention rests on two suggestions for guidance in the world in which we live. Most importantly we needed to make sense of where we are. Second, we need to draw on imagination, our best resource for truth and truthfulness in an uncertain world.

Plainly, this meant we needed to be liberated from an insulated, self-contained moral discourse. The "political" could not replace such a discourse and, indeed, should not. Rather, it could open us to alternatives found neither in the certainty of objective truth claims nor in radical skepticism. The "political" has integrity in that it can in itself be a source of normativity. Political theory can help shape the future if we give up our pretensions toward accuracy. This entails an honest encounter with the reality of political action. That is, political action is inherently opaque. Collective action requires sensitive security and other matters to be understood by the represented. Political action is reactive, sometimes requiring emergency action. Analysis necessarily remains incomplete, meaning those who want a more complete analysis simply do not want the action. Political action has unintended effects. The problem of accurate and sincere representation conflicts with collective passion and memories. In short, the opacity of political action means that the intelligibility required by adequate political theory (and by implication, moral theory) can be had largely through retrospection. If we want to shape the future it ought not be from a perfectly articulated and reasoned plan conceived prior to political action. Still, political action can be evaluated in light of the resources found in the humanities and the political and social sciences.

From this insight, calling attention to the opacity of political action, Williams developed a theory of democracy that confronted implicit and explicit power structures; a theory of justice that placed a premium on questioning the legitimacy of coercive power; a theory of war that cast suspicion on the justification of national self-defense and promoted a cast of mind that helped to understand the limits and possibilities of cultural identity, in a world where civilizational conflict has replaced even the tenacity of ideological determinism. He sent a message of hope but warned of the expectations of what we may hope for.

Michael J. Dubin University of Wisconsin, Madison 


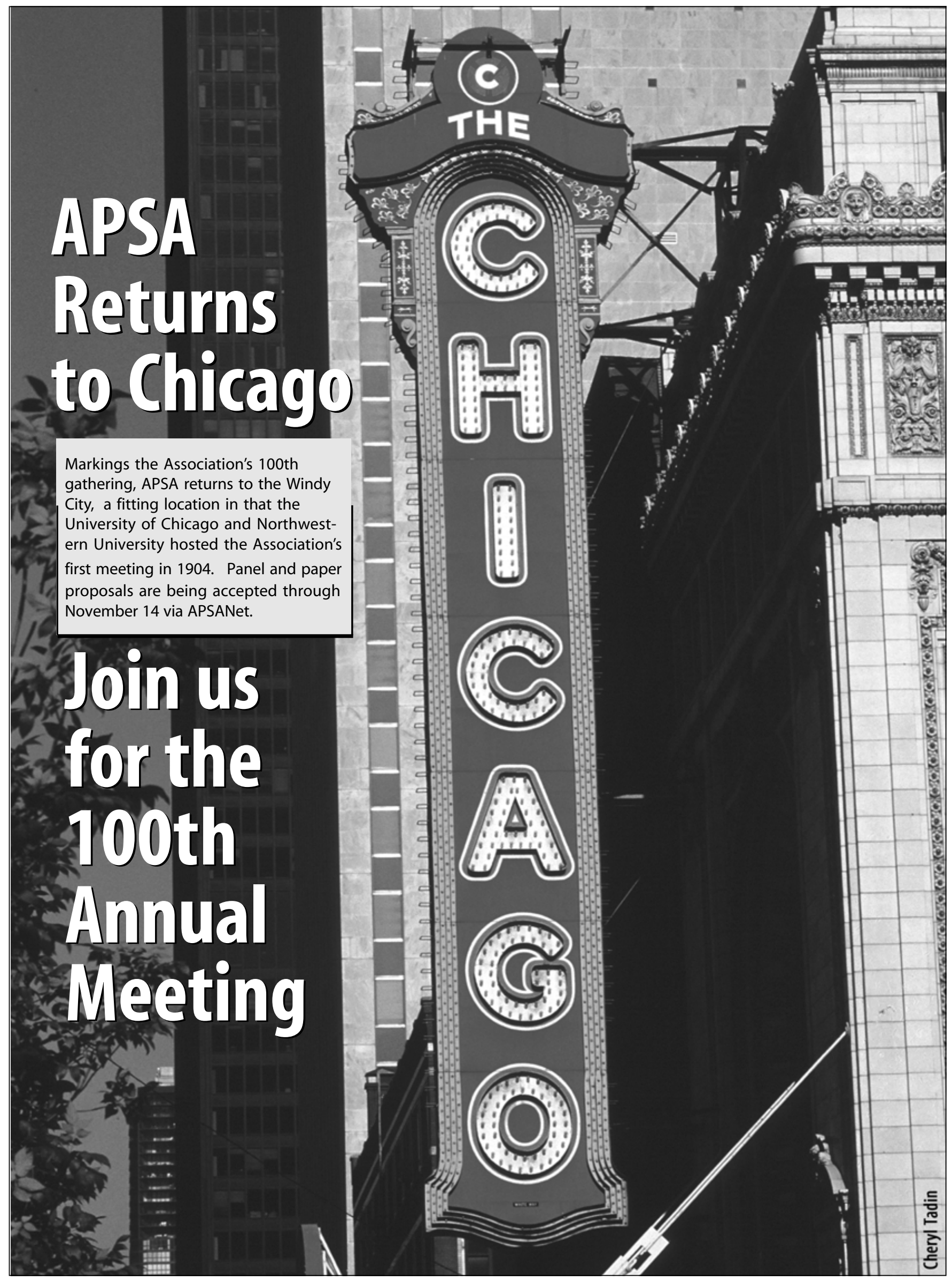

